\title{
PARTICIPLES IN CONTRAST
}

\author{
HANS PETTER HELLAND AND ANNELIESE PITZ \\ University of Oslo
}

\section{AB S T R ACT}

This article deals with the structure of present and past participles in French and German, occurring in open (lacking an overt subject: 'regardant les roubles', 'die Augen öffnend') and closed (with a subject: 'la distribution terminée', 'den Fuss erhoben') adjuncts. The analysis is based on material from the OMC-corpus. It will be shown that although the constructions in the two languages differ wrt to some properties such as case assignment, the structural account proposed permits to identify and describe these differences and to test some specific hypotheses with cross-linguistic implications.

\section{[1] INTRODUCTION}

In this paper, we will attempt to extend the structural analysis of past participles in open adjuncts presented for German and French in Helland \& Pitz (2012, chap. 3) to both present and past participles in the two languages. We will also include occurrences of participles in closed adjuncts in the analysis. Even though both German and French have similar constructions theoretically available, they choose different options for expressing the same semantic content. Crucially, the analysis we envisage will be based on the material in the OMC corpus ${ }^{1}$, most often through translation data with German and French either as source language or target language, but sometimes also through parallel data with both German and French as target languages for Norwegian originals. This allows us on the one hand to identify the idiosyncratic properties of the participle constructions in German and French, and on the other hand to test specific hypotheses with some interesting cross-linguistic implications concerning the structural properties of the various participial constructions.

We will start by introducing present participles and their properties in French and German, contrasting them to past participles where this is relevant. We then go on to study in more detail the structural build-up of the two types of constructions based on minimalist theoretical assumptions in a generative framework.

[1] The Oslo Multilingual Corpus (OMC) is a collection of text corpora comprising original texts and translations from several languages. For detailed information on the OMC Corpus, see http://www . hf . uio. no/ilos/english/services/omc/. 
[2] PRESENT PARTICIPLES ( P 1) IN CONTRAST

Present participles (P1) are non-finite sentence-like constructions missing in the general case an overt subject and phi-features (for tense, person, number) exhibiting however aspectual properties (Struckmeier 2007; Rapp \& Lübbe 2011; Embick 2003; Helland \& Pitz 2012). The questions we will try to answer are: How much structure do they project? How do we explain the differences between P1 and P2-constructions in French and German? In neither case can we talk about full sentence structures, but there are clear differences between them. In what sense are the verbal projections defective? We will see that the kind of evidence in the two languages as to structural properties differs, but that the same (amount of) structure for the constructions is potentially available in both languages. These are strong indications for a unitary theoretical framework with a common structural core.

We will start by describing the complex properties of the P1 before presenting the framework.

\section{[2.1] P1 - open adjuncts}

Examples (1)-(4) illustrate the type of construction we are interested in, including here examples from the languages we might want to investigate further, i.e. English and Norwegian. In (1) we find unergative P1s both in the German and French translations (of the Norwegian originals). In (2) and (3) we find transitive P1s respectively in German and French originals. (4) illustrates an unaccusative P1 (motion verb) both in the German and the French translation with obligatory adverbial (here source) ${ }^{2}$ :

(1) a. Dies und die Verwandlung, deren Zeuge er ist, die Auflösung des Mannes: willenlos, wie ein kraftloser Greis schluchzend, läßt er sich ohne Widerstand von den Männern abführen und in das wartende Auto setzen. (KF1TD)

b. De même que la métamorphose dont il est le témoin, la dissolution de l'homme: privé de toute volonté, reniflant comme un vieillard amorphe, il se laisse conduire dans la voiture qui attend. (KF1TF)

c. This, and the metamorphosis he is witnessing, the Man's disintegration: docile, sniffling like an unresisting graybeard, he lets the men convey him into the waiting vehicle. (KF1TE)

d. Dette, og forvandlingen den er vitne til, Mannens oppløsning: Viljeløs, snufsende som en motstandsløs olding lar han seg lede av mennene inn $\mathrm{i}$ den ventende bilen. (KF1)

[2] Actually Norwegian exhibits a participle construction only in (1d), the other examples revealing that the German and French participle construction may correspond to a Norwegian subordinate clause (2b), a main clause (3b) or a prepositional phrase (4d). 
(2) a. Städte lassen sich an ihrem Gang erkennen wie Menschen. Die Augen öffnend, würde er das gleiche an der Art bemerken, wie die Bewegung in den Straßen schwingt , ... (RM.1.1.s)

'Towns can be recognized by their way of walking, like people. Opening his eyes, he would notice the same in the way the movement swings in the streets, ...'

b. Byer kan kjennes på ganglaget akkurat som mennesker. Idet han åpnet øynene, ville han ha merket likheten i måten bevegelsen svingte på $\mathrm{i}$ gatene ... (RM1TN.1.1.s12)

'... While he opens his eyes, he would notice the similarity in the way the movement swings in the streets, ...'

(3) a. Regardant les roubles d'un oeil sarcastique, le marmiton maugrée: ... (KM1F.9. s.159)

'Looking at the roubles with a sarcastic eye, the servant ...'

b. Tjeneren betrakter rublene med sarkastisk blikk og roper: ... (KM1TN.9. s.181-182)

'The servant looks at the roubles with a sarcastic look and shouts: ...'

(4) a. Ich stelle sie mir in Istanbul, dem Paradies der Diebe, vor, gerade dem türkischen Bad entsteigend, ... (KF1TD)

b. Je me l'imagine à Istanbul, le paradis des voleurs, sortant tout droit du bain turc où la vieille habilleuse ... (KF1TF)

c. I imagine her in Istanbul, the thieves' paradise, just stepping out of the Turkish bath, where ... (KF1TE)

d. Jeg tenker meg henne i Istanbul, tyvenes paradis, rett ut fra tyrkerbadet, hvor den halvgamle ... (KF1)

'I imagine her in Istanbul, the thieves' paradise, right out of the Turkish bath, where ...'

From a contrastive point of view, a difference in word order is readily observed. In German, the participles follow the adverbial modifiers (1) and the complements (2)-(4) contrary to French (and Norwegian and English), thus reflecting the OV - VO distinction between the languages. Not surprisingly, the word order in German depends on the type of modification. In (1) where the modification is not valency-bound it can actually be altered, i.e. the P1 preceding the modifier ('schluchzend wie ein kraftloser Greis') while the P1 must follow the direct object noun phrase 'die Augen' 'the eyes' in (2a) and the source complement required by the verb 'entsteigen' 'step out' in (4a).

However, the main characteristic of these constructions observed in the examples is the lack of inflection, i.e. lack of phi-features (for tense, person and number) on the verb form. As far as concerns their temporal interpretation, it is dependent on the matrix verb and the syntactic surroundings (Fortmann 
2013). So in (1)-(4) the tense specification of the matrix carries over to the P1: while he lets himself be abducted, he is sniffling like an unresisting graybeard), cf. Fabricius-Hansen \& Haug (2012, chap. 1, 4). The event time of the present participle is included in the reference time of the matrix. Temporal inclusion however, is not the only possibility: the reference time of the P1 may (partially or completely) precede the reference time of the matrix (from Fortmann): 'fröstelnd betrat der Eremit das Fegefeuer' - 'shivering the eremit entered the purgatory'. As pointed out by Fortmann (2013), this is the case especially when the P1 consists of an individual level predicate. (See Rapp \& Lübbe (2011) for examples showing that $\mathrm{P} 1$ used can express any time reference: anteriority, posteriority and simultaneity. They treat attributive P1 only). We will have more to say about the discourse relations between the $\mathrm{P} 1$ and the matrix events in further works.

Replacing the P1 in (4) with the P2 illustrates a crucial contrast between the participles: 'dem Bad gerade entstiegen'- 'sorti tout droit du bain turc' - 'stepped out of the bath'. While the P1 expresses an ongoing event, the P2 refers to an accomplished event. Struckmeier (2007) proposed to describe the contrast as an aspectual one, i.e. imperfective vs. perfective, so do Rapp \& Lübbe (2011) and Weber (2000). A description in these terms seems to be largely on the right track and we will take it as additional support for positing an aspectual head in the syntactic structure. However, the aspectual properties of the participles cannot be captured by a simple +/- perfective, both the class of P2 (Helland \& Pitz 2012) and the $\mathrm{P} 1$ require finer distinctions. The imperfective aspect (or viewpoint aspect in the Smith (1997) sense) being associated with an unbounded interval, it is clear that $\mathrm{P} 1$ is not inherently imperfective:

(5) Den Betrachter oben am Schüsselrand bemerkend, verstummten sie und starrten mich an, reglos, auf dem Sprung. (PH1)

'Noticing the observer above the edge of the plate, they turned silent and stared at me, motionless, ready to jump.'

(6) Relevant la tête, elle fixe Sâdiyé, avec toute la hauteur dont elle est capable. (KM1F s.8)

'Lifting her head, she fixed Sâdiyé with all the highness of which she was capable.'

The events of noticing (5) or raising her head (6) are not open-ended, and they do not (at least not in the strict logical sense) overlap with the matrix event of becoming silent or starting to look at Sâdiyé. So, the P1s in (5) and (6) are clearly not inherently imperfective (nor perfective), but the intuition of an aspectual value ("outer aspect") assigned to the participle is still worthwhile pursuing.

As to the other phi-features and properties of the P1 construction, the subject of the matrix is understood as the non-expressed subject of the P1 construction, 
a property shared by the P2 except closed adjuncts (see below). This means that it is the subject of the matrix in (2) ('er') and (3) ('le marmiton') which control the implicit subject of the non-finite construction. Note that here too there may be exceptions - see Fortmann (2013) for an example where the condition seems to be that the P1 be related to the participant with the highest role -, but this phenomenon can be readily be handled by control theory (see for instance Helland (2013)).

A further common property for French and German concerns the verb itself. There are no restrictions with respect to the verb type (or root - see below) on the formation of the P1 (as opposed to P2 as we will show later). As we have seen in (1)-(4), unergatives, transitives and unaccusatives may occur as P1. Interestingly, the P1 constructions must contain all the arguments the verb (or the root form) projects. Arguments can and must be realized. In addition, when the verb is transitive, accusative case is assigned to the direct object in German. Only the external argument is not overtly expressed. This is a fundamental property of the P1-construction that we will exploit in the following.

Example (7) illustrates yet another phenomenon. As in sentential constructions, there are binding relations, the reflexive sich must be bound by a subject. See (7c) for the sentential equivalent, where the subject 'er' refers to the subject of the matrix. Reflexive binding will thus be taken as an indication for the presence in structural terms of a binder.

(7) a. Er wandte sich ab, ein bißchen zu heftig, und ging, das Ende der Peitschenschnur hinter sich herschleifend, über den Domänenhof zu den Ställen hinüber, und Regine Ziemek brauchte nicht zu fragen, welch eine Zukunft für sie herausgesprungen war, als er sich blicklos am Geflügelhof vorbeibewegte. (SLE1)

'He turned away, a little too curt and went over the yard to the stables, dragging the end of the whip after himself, ...'

b. ... *(das Ende der Peitschenschnur) *(hinter sich) herschleifend

c. ... indem/wobei/während er das Ende der Peitschenschnur hinter sich herschleifte

'... as/ while he dragged the end of the whip after himself'

Example (8) illustrates the same, 'einander' 'each other' being bound by the implicit subject argument of the participles which themselves are controlled by 'eine Gruppe von Idioten' 'a group of feebleminded people' in the matrix.

(8) Und doch habe ich einmal einen Zug in der Stadt gesehen: eine Gruppe von Idioten, einander auf die Schultern schlagend, schubsend und im Schwitzkasten haltend, schwärmte da von Andenkenladen zu Andenkenladen; ihre 
gute Laune war Freude: Ausgang zu haben; in der Stadt zu sein. (PH1) 'And yet I once saw a procession in the city: a group of feebleminded people, slapping each other on the back, pushing and wrestling, swarmed from souvenir shop to souvenir shop;'

This is exactly the same in French where we find reflexive clitics being bound by the implicit subject argument of the (present) participle construction.

(9) Se hissant sur la pointe des pieds, Selma a essayé d'apercevoir son cousin préféré. (KM1F.3. s.138)

'Rising to the tip of her toes, Selma tried to see her preferred cousin.'

Thus, both German and French exhibit binding facts that point to a rather elaborated sentence structure for P1-constructions (with an implicit subject binder). Even more strikingly, in French, P1 combines with (sentential) negation through "ne-pas" and this strongly suggests that the present participle construction is sentential in nature.

(10) On dit que les Norvégiens ne prennent pas de répit avant de n'avoir accompli toutes leurs multiples besognes. Ne trouvant plus d'autres tâches, ils se créent des activités pour se faire souffrir: des promenades dans les forêts ... (GJ1TF.9. s.4)

'... Not finding other activities, they create activities to make themselves suffer: walks in the forest ...'

As is well known, the negation phrase in French projects above the (lower) verbal domain. The present participle in (10) must therefore be raised to a higher head position in the structure where it can be associated with the ne-clitic. Even more than one clitic form ("ne" and "se") can be combined (or head-adjoined) with the raised verb form as in (11):

Elle m'apprit que, ne se limitant pas à quelques rares moments " intimes ", l'érotisme est omniprésent entre les êtres. (KF1TF.2.1. s.36)

'She taught me that, not limiting herself to some strange intimate moments, ...'

We will come back to how this can be implemented below, but before we do that we will introduce an additional fact about the P1-construction that is particularly revealing for our purposes.

[3] Example (8) can be used in the discussion concerning inner aspect that we will continue in further works. An Asp node is responsible for the Aktionsart: schlagen 'to hit' is punctual, so is schubsen 'to push'; other verbs: die Augen öffnend 'opening the eyes', se penchant 'leaning'. 


\section{[2.2] P1 - closed adjuncts}

Both in French, and to a lesser extent in German, P1s can enter into small clause constructions, known from Fabricius-Hansen \& Haug (2012) as "closed adjuncts" or from traditional grammar as "absolute constructions" where the non-finite verb form has an explicit subject.

(12) a. Und starrte eingehend auf jeden einzelnen Kutscher, der hocherhobenen Hauptes auf dem Kutschbock saß, die Peitsche auf dem Knie ruhend. (HW2TD)

b. Et dévisageait chaque cocher, assis bien haut, le fouet reposant sur un genou. (HW2TF)

c. Og stirret inngående på hver enkelt kusk, som satt kneisende med svøpen hvilende mot kneet. (HW2)

d. And stared intently at each coachman who sat straight and proud with a whip resting against his knee. (HW2TE)

In written French, this is quite a common structure allowing all types of verbs: unergatives in (12), unaccusatives in (13), direct and indirect transitives in (14)(15):

(13) Les années passant, il supporte de plus en plus mal son rôle de prince consort. (KM1F.3. s.50)

'The years passing, he endures ...'

(14) La nature faisant bien les choses, les femelles oublient les rejetons d'une saison pour consacrer toute leur énergie ... (CC1F.3. s.8)

'Nature doing things well, ...'

(15) Elles sont en grande discussion, la sultane reprochant à sa cadette d'assister aux réceptions données régulièrement par l'ambassade de France. (KM1F.11. s.246)

'They are engaged in a big discussion, the sultana reproaching her youngest sister for assisting at the receptions given regularly by the French embassy.'

Yet again there is no doubt about the sentential nature of the construction. Closed adjuncts in French combine easily with both clitics and ne-pas-negation:

(16) La porte ne s'ouvrant pas assez vite à son gré, il la pousse, entre et se met à encombrer le couloir de ... (KF1TF.2.16. s.6)

'The door not opening fast enough for him, he pushes it open, enters and ...' 
This constitutes a difference between French and German. Even though closed adjuncts with P1 are also theoretically available in German, only a few instances with nominative case are observed. (17) is a case in point:

(17) Eine Birke stand weiß im Finstern, mit allein vom fallenden Schnee bewegten Hängeruten; ein einzelner Ast vibrierend im Leeren: da mußte gerade ein Vogel aufgeschwirrt sein. (PH1)

'... a single branch vibrating in the emptiness: a bird must just have buzzed off.'

'vibirieren' is an unergative verb and the noun phrase 'ein einzelner Ast' 'a single branch' is clearly identifiable as a nominative. Nominative case can sometimes be undistinguishable from accusative as for instance in (12) above, repeated here, where 'die Peitsche' could be either case:

Und starrte eingehend auf jeden einzelnen Kutscher, der hocherhobenen Hauptes auf dem Kutschbock saß, die Peitsche auf dem Knie ruhend.

However, 'ruhen' 'to rest' being an unergative verb, the DP must be interpreted as the subject, hence as a nominative DP. At first sight, in the absence of phifeatures this could seem surprising. At the same time, 'ruhen' cannot be intended as a transitive verb here. Not only would such an interpretation go counter to the original version and the translation into English and French, the transitive construction in (19b) seems also highly questionable:

a. Die Peitsche ruht auf dem Knie.

'The whip rests on the knee'

b. ?? Er ruht die Peitsche auf dem Knie.

'He rests the whip on the knee'

Since the syntactic structure for P1 has to be elaborate due to negation and clitic placement in French, we may assume that nominative case in these constructions can be taken as an indication that the syntactic structure for German is no less elaborate. The sole argument of the unergative 'ruhen' 'to rest' in (18) and 'vibrieren' 'to vibrate' in (17) then has to move up to the C-T-domain to license nominative case. In fact, we find further arguments in favor of such an elaborated P1-structure in other cases.

(20) a. Das waren Rakel und ihre Mutter. Die Mutter sterbend, vielleicht bereits tot, Haut und Knochen, in Fetzen gekleidet, die Haut über den Schädel gezogen ... (JW1TD.1.1. s.45)

b. C'étaient Rakel et sa mère. La mère agonisante, à moins qu'elle ne soit déjà morte, la peau sur les os, en haillons le cuir chevelu distendu ... 
(LSC3TF.3.8. s.304)

c. Det var Rakel og moren hennes. Moren er døende, kanskje død allerede, skinn og bein, kledd i filler, huden strukket over kraniet ... (LSC3N.3.8. s.288)

'It was Rakel and her mother. The mother dying, perhaps already dead, skin and bones, dressed in rags, the skin drawn over the skull ...'

'sterben' 'to die' is without doubt an unaccusative verb that forces the sole argument to be marked for nominative case. There is no other alternative. If then the C-T-domain is the locus for nominative case licensing, as is standardly assumed, this means that the structure in (20a) must be a (defective) sentence structure.

\section{[2.3] P1 - a structural account}

We will use the evidence above - clitic placement and negation in French, argument realization through morphological and abstract case both in German and French - to propose a rather sentence-like structure for open adjunct P1.

For a transitive P1 in French like 'regardant les roubles' 'looking at the roubles' we posit a lower verbal projection like in figure 1 :

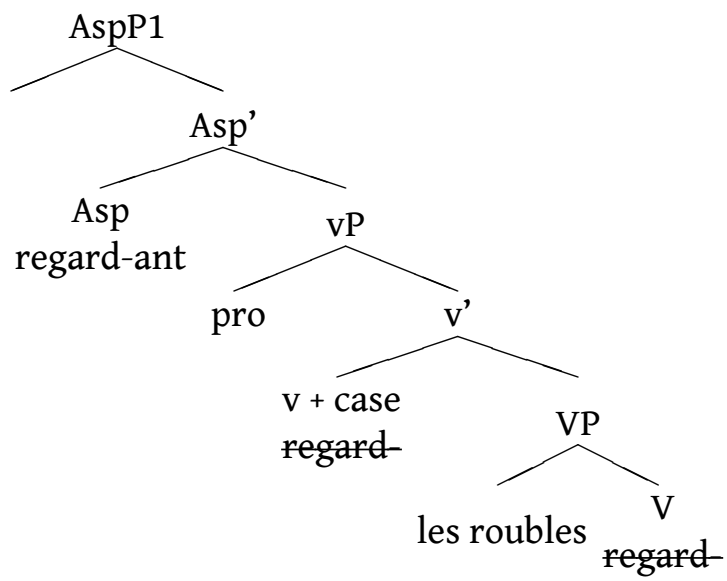

FIGURE 1: Transitive P1 'regardant les roubles'

Following rather uncontroversial assumptions, we let the verbal root appear under the V-node in the VP and putting the internal argument-DP ('les roubles') in the specifier position of VP. VP is selected by a functional head $\mathrm{v}$ which comes with specific case features. It can be marked either as +case or -case, that is it can license accusative case to the object. A $\mathrm{v}+$ case will also by Burzios generalization (according to which a verb that does not have an agent argument in the specifier position cannot check objective case, and conversely, see Burzio (1986) assign a role to the external argument, in this case a null argument called (little) 
pro. At the left edge of the lower verbal domain, we have an Asp-phrase, tentatively called AspP1 (for present participle), which is responsible for the present participle morphology, in German (-END) or in French (-ANT). The motivation for an Asp-phrase will be given below.

We will also say that the spec, AspP-position for P1 (and for transitive verbs in the perfect tense in German - see below) is a potential landing site for the accusative object in German that is moved to the left of its verb (through the OVcondition).

For P1, however, as we have seen, we have to posit more structure above the lower verbal domain (that is the AspP with its complements). This is so because the present participle may move above the negation phrase and the clitic phrase in French. Uncontroversially, both the Neg-phrase and the Clitic-phrase in French are situated above the AspP. We therefore suppose a C-T-domain for P1 to which the participle form must move and license a (pro-) subject in spec, TP.

For our example in French, this means the steps shown above the AspP1 in figure 2 .

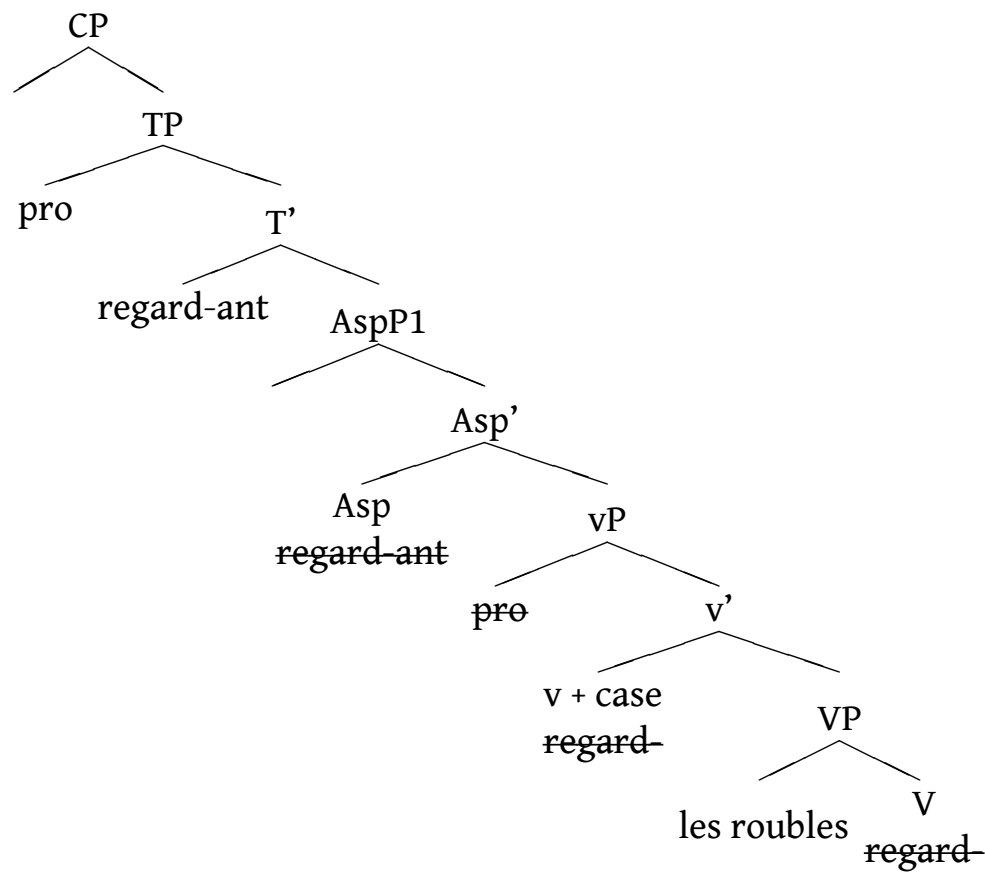

FIGURE 2: C-T-domain for P1

For an equivalent example in German, the only difference in overt syntax would be that the object DP would have to move to spec, AspP1 through the OV- 
condition. In addition to this we would say that the pro-subject raises to spec, TP due to a EPP-feature on the T-head.

Exactly the same system will be applied to P1 as closed adjuncts, but with a very important addition. In this case, the spec, TP must be filled by a full DP. There is a case feature on $\mathrm{T}$ which licenses the nominative DP. However the Thead is defective in the sense that there is no person feature on it which means that there is no person ending on the verb.

For an example like (14) 'La nature faisant (bien) les choses' - 'Nature doing things (well)', we would therefore have the steps in figure 3.

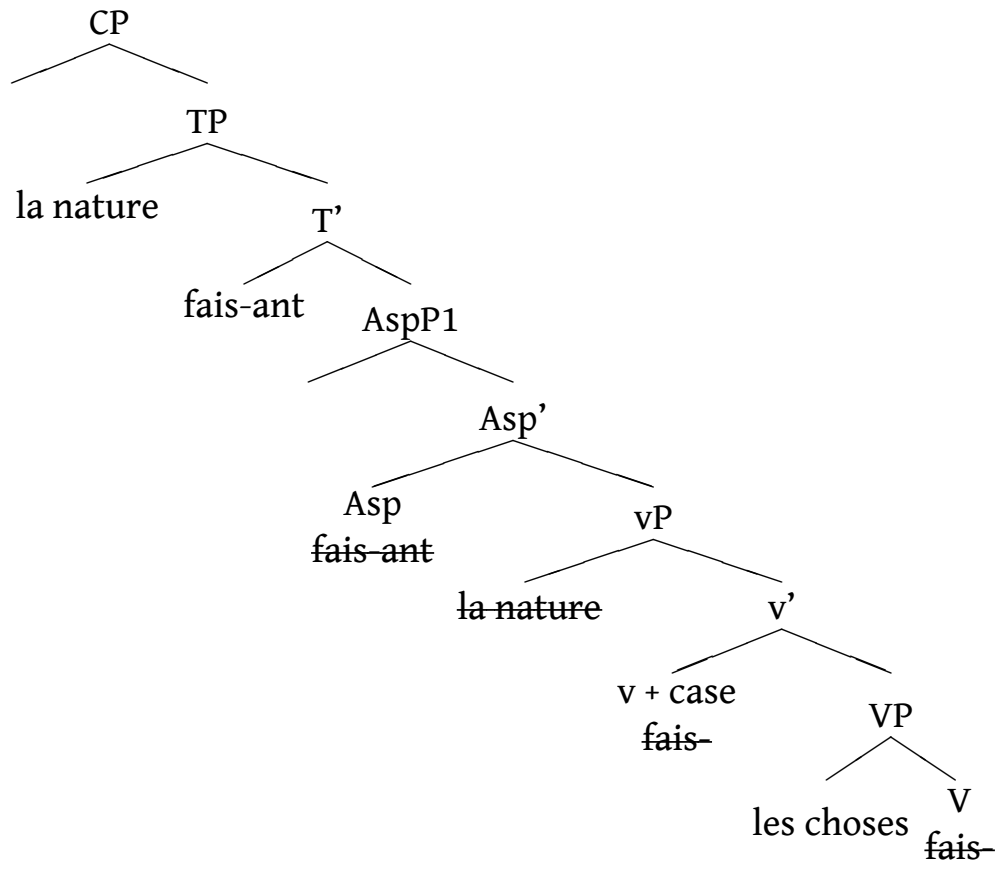

FIGURE 3: Structure for closed adjuncts

For the German example in (12)/(18), 'die Peitsche (auf dem Knie) ruhend' 'the whip resting on the knee', the treatment would be parallel with the subject DP ('die Peitsche') moving up to the TP along with its participle ('ruh-end').

\section{[3] PAST PARTICIPLES IN CONTRAST}

\section{[3.1] P2 - open adjuncts}

So far we have given evidence for positing elaborate sentence like structures for both open and closed P1-adjuncts. We now turn to past participles (P2). Contrary to the P1-construction which puts no restrictions on the verb classes entering into it, there are severe constraints on the P2-construction. P2s are formed 
from unaccusatives and passive predicates, hence the selecting verb cannot assign accusative case. Through Burzios generalization, the external argument is then unavailable.

In (21)-(24) we find examples of the two types in both languages:

(21) In die Wohnung zurückgekehrt, aß ich im Dunkeln einen Apfel. (AOH1TD) '(Having) returned to the flat, I ate an apple in the dark.'

(22) Eine Weile standen sie so mitten auf dem Weg, scheu betrachtet von zwei älteren Leuten, ... (DW1D)

'For a while they stood like this in the middle of the road, timidly observed by two elderly people ...'

(23) Rentré de la ville joyeuse avec un porte-monnaie plus léger, il avait la tête remplie de nouvelles impressions ... (AOH1TF)

'(Having) returned from the joyous city with a lighter purse, but with the head full of new impressions, he ...'

(24) Alerté par les eunuques, le vieux médecin du palais a rapidement examiné le "cadavre " qu'il a trouvé en mauvais état. (KM1F.12. s.306)

"Alarmed by the eunuchs, the old doctor of the palace rapidly examined the body which he found in a bad state.'

P2-constructions formed from unergatives or active transitives are however completely out:

(25) *Dansé toute la journée, il est retourné à la maison.

'(Having) danced all day, he returned home.'

(26) *Lu le livre, il s'est couché.

'(Having) read the book, he went to bed.'

From this it follows that only verbs without external arguments (and hence no possibility to assign accusative case) are possible in the P2-construction.

In the traditional literature, one usually establishes a binary distinction for the interpretation of (full) passive structures like (27):

(27) The door was closed.

This distinction is often labeled verbal vs. adjectival passives saying that the passive interpretation can either be eventive (for the verbal passive) meaning that "the door was closed by someone at a particular time in the past" or stative (for the adjectival passive) meaning that the door was in the state of being closed. In Helland \& Pitz (2012) we showed that this picture was too simplistic building on Embick's theory of resultative participles in English (Embick 2004). In our Embick- 
based system, passive participles may have either an eventive interpretation for the dynamic passive as in (28):

(28) Réveillée par cette avalanche, Tora entendit Henrik s'affaler en jurant. (HW1TF)

'Woken up by this avalanche, Tora heard Henrik ...'

'Tora woke up when the avalanche began. She heard that he fell down in there and heard him swear.'

A resultative interpretation in which the eventive character of the past participle has been changed into a state without losing its relation to the verbal source:

(29) Peinte en gris-bleu, elle (= la maison) avait un soubassement blanc pourvu de quatre fenêtres ... (GS2TF)

... painted-F.SG. in grey-blue, it-F.SG. had ...

And finally a (real) stative interpretation without the participle being related to a (preceding) verbal content at all. Hence in (30), we could speak of a fully adjectivized past participle:

(30) Déçue, Selma baisse la tête. (KM1F9 s.115)

'Disappointed, Selma lowered her head.'

We extended the Embick-system both to open adjuncts formed from passive participles and to other verb classes, for instance unaccusatives in (31), but also to reflexive (unaccusatives) and psych-verbs:

(31) Oben angekommen, begriff ich dass sie sich verspätet hatte. (BHH1TD) 'Arrived upstairs, I understood that she was late.'

In (31), it is clear that understanding takes place in the resultant state of the preceding (unaccusative) event, thus there can be no question about an adjectivized P2. The three-ways interpretation of the P2 was constructed through an Aspect Phrase (AspP) that we, located, just like Embick, at the left edge of the verbal domain (vP). The root-form, whether verbal or adjectival, moved to the aspectual head to pick up participial morphology. The three possibilities of interpreting the P2s were then related to features on the aspectual head. In Helland \& Pitz (2012), we distinguished a dynamic (or eventive) asp-head (Asp $\mathrm{DYN}_{\mathrm{DYN}}$ ), cf. figure 4 on the following page, a resultative asp-head, figure $5\left(\mathrm{Asp}_{\mathrm{R}}\right)$, and a stative (adjectival) asp-head $\left(\mathrm{Asp}_{\mathrm{S}}\right)$ in figure 6. In this paper, we distinguish the AspP for P1 (AspP1) from the equivalent structure for P2 by calling the latter AspP2.

Figure 6 corresponds to the fully adjectival readings and is not of our concern in this work at all. What is important for us here is that the asp-heads in figures 4 and 5 take verbal projections (vP) as complements and that this vP must be 


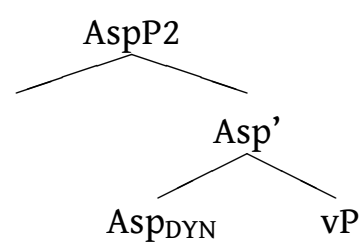

FIGURE 4: Dynamic (eventive) Asp-head Asp $p_{\text {DYN }}$

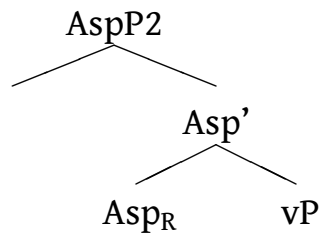

FIGURE 5: Resultative Asp-head Asp

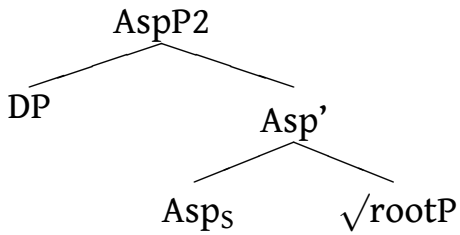

FIGURE 6: Stative Asp-head Asps

defective in the sense that the verbal head does not assign an external argument. By locating the participial morphology in the aspectual head, the verb root raises to this position and the (sole) internal argument of the root (= pro) passes through the empty specifier position of vP on its way to its landing site in spec, AspP2, as in figure 7 on the next page.

The -case feature on the verb means that the v-head is not able to license accusative case. Therefore the spec, vP-position is empty and the (null) internal argument of the root - located in spec, VP - can pass through spec, vP on its way up to spec, AspP2 (= its landing site) for EPP-reasons.

Note that in French, both clitics and ne-pas-negation are completely ungrammatical in P2-constructions:

(32) *Se penché vers le mur, il fumait sa cigarette.

'Leaning against the wall, he smoked his cigarette.'

(33) *Ne se penché pas vers le mur, il continuait à fumer.

'Not leaning against the wall, he continued to smoke.' 


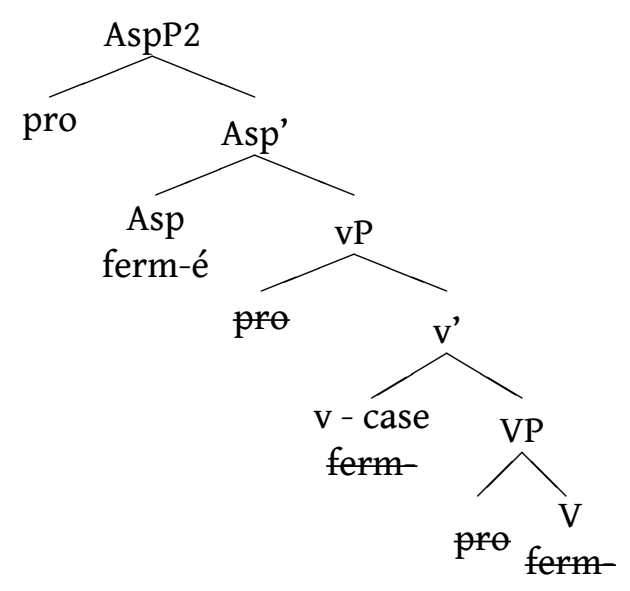

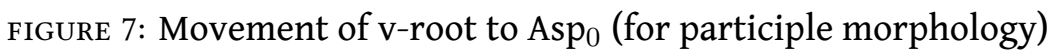

There is thus no reason for positing a sentential structure above the left edge of the vP (= AspP2) for French P2. We will adopt the same analysis for the German P2s in (21)-(22) and (31).

\section{[3.2] P2 - closed adjuncts}

Just like with P1, there exists a closed adjunct type that we find in both French and German. We illustrate the type first with French data, because the closed P2 in French receives a rather straight forward treatment in our framework. The German data are more complex and we come back to them below.

In both languages, however, we find the same restrictions on the verb types like with open adjunct P2. That is, the construction is only possible for passives (35)-(35) and unaccusatives (36):

(34) Les yeux fixés sur Djahane, il cherche le sentiment qu'il éprouve à son égard ... (AM2F.5. s.14)

'His eyes fixed on Djahane, he searches for the feeling he has towards her.'

(35) La distribution terminée, les serviteurs ont commencé à démonter planches et tréteaux lorsque Selma voit arriver un homme ... (KM1F.9. s.150)

'The distribution finished, the servants have started to disassemble the wooden tables ...'

(36) La quarantaine passée, il se maria avec Armande Rosalie Dransart, de dixsept ans sa cadette. (CFFG1F.1.2. s.5)

'The age of forty passed, he married Armande Rosalie Dransart, ...' 
In all these cases, whether passive or unaccusative, it's reasonably clear that the events of the matrix are located in the resultant phase of the P2. In (34), it's after having his eyes fixed on Djahane that he is searching for the feeling he has for her. In (35), the servants of course start disassembling the wooden table after the ceremony is finished, and in (36), the subject referent marries ARD after celebrating his forty years. So, in the temporal sense of the AspP2, the Asp-head in (34)-(36) must have the feature $\mathrm{R}$ (esultative).

What is more intriguing, is that the subject DP of the P2-construction must have a case licenser. Since P2s do not project above the AspP2 (that is the left edge of the lower verbal domain) and since the DPs in these cases are clearly not an accusative marked DP - recall that the v-head bears a minus (accusative) case feature -, the only way to license the case feature on the DP is to have it moved to the spec, AspP2. We will say that (abstract) case marked DP subjects in French P2-constructions bear a nominative case feature. This feature is licensed by the Asp-head. We therefore have the structure in figure 8 for an example like (35) "la distribution terminée".

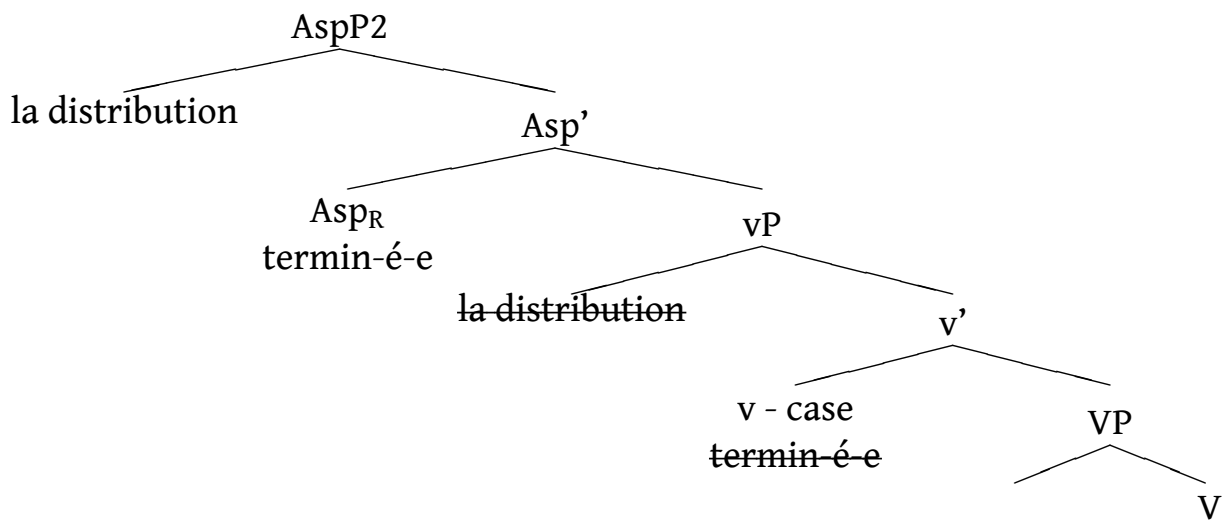

ladistribution termin-

FIGURE 8: Structure for P2 in closed adjuncts

This is of course an entirely parallel way of treating open adjuncts of the French P2-type besides the fact that for the closed type there is an explicit DP subject being (nominative) case licensed by the Asp-head.

\section{[3.3] German - closed P2}

If our system is generally valid, it should be a way of handling the German facts by using the same mechanisms. The difference is that German DPs are morphologically marked for case. And indeed there are examples from German where the DP is case marked by the Asp-head for nominative: 
... der Körper gespannt wie ein Flitzbogen

(Fabricius-Hansen \& Haug 2012, 63)

'... the body stretched like a bow ...'

(38) a. Auf dem Weg in die Küche komme ich am Spiegel vorbei, wo ich das deprimierende Bild eines Hundes in all seiner Jämmerlichkeit auffange. Das Haar ungewaschen und ungepflegt, in langen Wellen zu beiden Seiten eines Gesichts, das unnatürlich lang und schmal wirkt, wie das Gesicht eines irischen Wolfshunds, mit spitzer, hängender Nase, rötlichem, ungestutztem Bart, tiefsinnigen, blutunterlaufenen Cockerspaniel-Augen. Der Nacken geduckt, der Rücken gekrümmt, der Gang schleichend.

(KF1TD.2.14. s.159)

'... The neck ducked, the back bent, the walk creeping ...'

b. På vei til kjøkkenet går jeg forbi speilet hvor jeg får et deprimerende glimt av hunden $\mathrm{i}$ all dens ynkelighet: Håret uvasket og uappetittelig $\mathrm{i}$ lange bølger hengende ned på begge sider av et ansikt som virker unaturlig langt og smalt, som ansiktet til en irsk ulvehund, med spiss, hengende nese, rødlig, utrimmet skjeggvekst, tungsindige, blodskutte Cocker Spanieløyne. Nakken lut, ryggen krum, gangen luskende. (KF1N.2.14. s.155)

In (37) and (38), there are three DPs marked in the nominative (besides the DP subject of the P1 schleichend, i.e. 'der Gang' which is also nominative, but in that case marked from the T-head - see above): 'der Körper (gespannt)' - 'der Nacken (geduckt)' - 'der Rücken (gekrümmt)'. In all these cases, we can speak of inalienables, the body parts being inalienable (or no-separable) parts of the subject referent ('der Hund' 'the dog'). The P2s (ge-spann-t-ge-duck-t-ge-krümm-t), which all have underlying internal arguments, do have DP-subjects in the nominative. The treatment of these cases would then be entirely parallel to the French cases in (34)-(36), the DP subject being case marked by the Asp-head in the lower verbal domain.

At the same time note that the P2s in (38) are both translated from (nondeverbal) adjectives in the Norwegian original. This could mean that these German P2s could also potentially be seen as elliptical copula constructions:

Der Körper (ist) gespannt - Der Nacken (ist) geduckt - Der Rücken (ist) gekrümmt.

'The body (is) stretched - The neck (is) ducked - The back (is) bent'

Whatever solution is chosen, this would not be a problem for our treatment because, in the latter case, the DP-subjects would be case licensed by the T-head which carries a nominative case feature. So, in both ways, whether by the Asphead (in the P2-construction) or the T-head (in the (elliptical) copula construction), the nominative DP-subject will be licensed. 
With inalienables, there also exists a construction in German termed the absolute accusative which raises questions for the treatment of P2-adjuncts. This construction is illustrated in (40)-(42):

(40) a. Ein Wächter ist ein Mann, der finster und wild entschlossen blickt, einen Fuß wie zum Tanz erhoben, und dabei eine Keule schwingend, die aus einer Blume gemacht ist. (ROB1TD)

b. A guardian is a man with bulging brows and fierce will, foot raised as if to dance, who lifts a club made of a flower. (ROB1)

(41) a. Die Strafe selbst ignorierte er. Den Mund geschlossen, den Blick auf die ferne Welt gerichtet, so überstand man alle Tage der Korrektur.

(SN1D.1.3. s.100)

'... His mouth closed, his look directed towards the distant world ...'

b. Selve straffen ignorerte han. Med lukket munn og blikket rettet mot den fjerne verden utstod man alle forbedringsdager. (SN1TN.1.3. s.101)

(42) a. Überall am mageren Körper treten die Knochen hervor. Den Schwanz zwischen die Hinterläufe geklemmt. Es fehlt nicht viel, und ich jaule vor Mißmut und Kummer beim Anblick der Reste meines Ichs.

(KF1TD.2.14. s.159)

'... His tail clamped between his hind legs.'

b. Knoklene stikkende ut overalt på den magre kroppen. Halen klemt inn mellom bakbena. Det er såvidt jeg ikke gir fra meg et ul av mismot og pine der jeg står og ser på restene av meg selv. (KF1N.2.14. s.155)

Just like in (37) and (38), we have instances in (40)-(42) of German inalienables ('einen Fuss' 'a foot' - 'den Mund' 'the mouth' - 'den Blick' 'the look' - 'den Schwanz' 'the tail'), but this time the (body part) DPs are marked for the accusative case. Apparently, this raises some problems for our treatment since we have stated that unaccusative and passive P2s are not able to case mark DP objects for accusative. Since the $\mathrm{Asp}_{\mathrm{DYN}}$-head and the $\mathrm{Asp}_{\mathrm{R}}$-head are minus (accusative) case, there is no way that accusative case can be assigned in AspP2.

So far we have argued for the distinction between three types of Asp-heads for the three types of P2 constructions we have identified: Asp DYN - Asp $_{R}-$ Asps $_{s}$. These heads are the locus of past participial morphology just like the AspP1-head is responsible for the present participle morphology. What seems to be lacking is a head which provides the morphology for active past participles, i.e. for the (active) past participle. In the normal active transitive case, the head selecting vP to form the active past participle is an Asp-head - this AspP is then selected by a vAux which again is selected by Tense to provide the required phi-features for a present perfect structure. (In accounts not especially dealing with participles, as 
for instance D'Alessandro \& Roberts (2008), the participial morphology is a feature of a $\mathrm{V}$, selecting the VP.)

For participles like ge-schloss-en-ge-richt-et-ge-klemm-t, the auxiliary in question is haben: cf. 'Er hat den Fuß erhoben' 'He has lifted the foot' - 'Er hat den Mund geschlossen' 'He has closed his mouth' - 'Er hat den Blick auf die ferne Welt gerichtet' 'He has directed his look towards the distant world' - 'Der Hund hat den Schwanz zwischen die Hinterläufe geklemmt' 'He has clamped the tail between the hind legs'.

Importantly, the vP selected by the AspP2 can be either +case or -case. Since we want to explain the accusative assignment, we trace the structure for $\mathrm{v}+$ case. The feature $\mathrm{v}+$ case means that we have a subject as well in Spec of vP. This is what we find in active transitives. In the normal transitive present perfect, the subject will consequently move to (the subject position of) Spec, vAux and to Spec,TP for EPP-reasons, (nominative) case-, tense- and person-features as illustrated in figure 9.

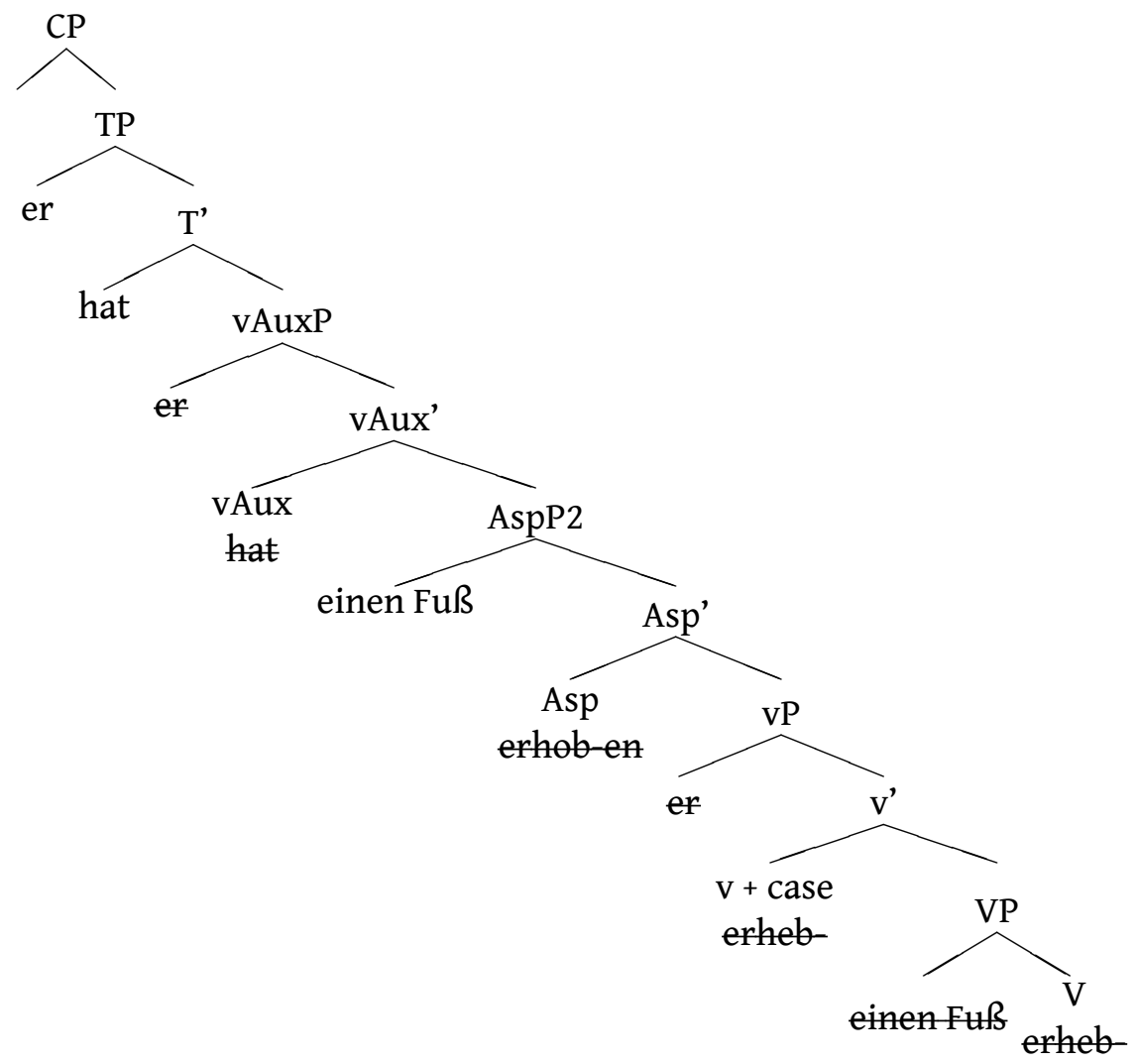

FIGURE 9: Structure for transitive present perfect 
But it is not sure that (40)-(42) are elliptical active constructions based on figure 9 . These really resemble $\mathrm{S}$ (mall) $\mathrm{C}$ (lause)-constructions in the traditional sense (see Bowers $(1993,2001)$ ) with an underlying haben (or avoir) as full verb(s). ${ }^{4}$ In all these cases, the DP (accusative) object must be licenced even if there is no explicit verbal licencer in the context.

In order to achieve this, we crucially have to posit some special feature in the active AspP2 keeping its spec-position available as a landing site for the accusative object in German just as with accusative objects in P1-constructions ('die Augen offnend' - 'opening the eyes'). Recall that the passive and unaccusative AspP2 does not have an accusative feature, nor an external argument. In the latter case, $v$ -case means that the verb is unable to license accusative case. For passives and unaccusatives, the specifier position of AspP2 is therefore a nominative case position to which the explicit internal argument (in the closed adjunct) can move and get nominative case. For the German absolute accusative, we postulate instead a (silent) haben-construction as an active, full verb which licences the accusative case on the DP-object, cf. figure 10.

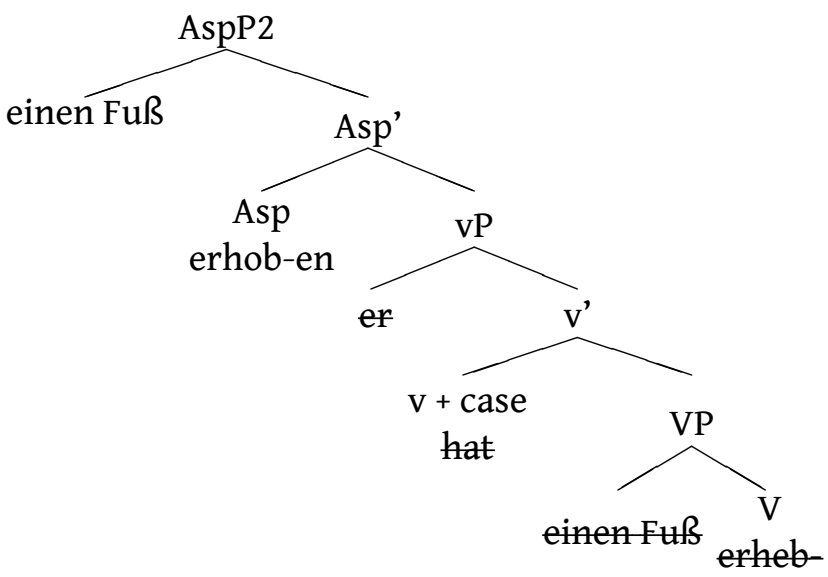

FIGURE 10: The German absolute accusative

The difference between German OV and French VO is consequently, in our account, handled through the spec, AspP-position both for active transitives in the perfect tense, (active) small clause structures and (active) P1s. The external argument for these cases, when expressed, just moves past this position to a higher

[4] In addition to (40)-(42), we could have both verbal and non-verbal (small clause-) structures like: Die Hände erhoben 'the hands lifted' / hoch 'high' / in der Tasche 'in the pockets' ... in which the predicate part is either a participle phrase, an adjectival phrase or a prepositional phrase. It's of course possible to give a uniform characterisation of these types of structures, for example through the predication phrase framework of Bowers $(1993,2001)$. In this paper, however, we are interested in non-finite verbal adjuncts, so we will stick to the vP-analysis. 
node, spec, for instance vAuxP and spec, TP which are, as we have seen, specific subject positions.

\section{[4] CONCLUDING REMARKS}

In this paper we have shown how to handle both open and closed P1- and P2constructions in German and French. The difference between the two types of construction concerns the availability of an explicit (for the closed type) or an implicit (for the open type) DP subject. We have extended our treatment from Helland \& Pitz (2012) using a DM-inspired system for P2 with an AspP2-phrase at the left edge of the lower verbal domain. The verb root raises to the Asp-head position in order to have past participial morphology. We have introduced a new AspP1 for present participles. Crucially there is a case difference between the properties of the v-head in P1 and P2. Only P1s can assign accusative case to the internal argument and a role to the external argument. Comparative facts between German and French show that the vP of P1 is (far) less defective than that of the P2.This entails that only $\mathrm{P} 1 \mathrm{~s}$ project above the lower verbal domain to the $\mathrm{C}$ T-domain accounting for case assignment in closed P1 for both languages, movement patterns, (lack of) constraints on the verb types, object positions in German and French, cliticisation and negation patterns in French and so on. In contrast, P2s do not project beyond the lower verbal domain. What is entirely new in our treatment is that we have introduced specific Asp-phrases both for P1 and P2. The Asp-phrases are overtly represented in syntax through non-finite verb morphology and display different properties dependent on homonymous Asp-heads. In this way, we can account for idiosyncratic facts about German and French with far reaching cross-linguistic implications.

\section{REFERENCES}

Bowers, J. 1993. The syntax of predication. Linguistic Inquiry 24. 591-656.

Bowers, J. 2001. Predication. In M. Baltin et al (ed.), The Handbook of Contemporary Syntactic Theory, London: Blackwell.

Burzio, L. 1986. Italian Syntax: A government-binding approach. Dordrecht: Kluwer.

D'Alessandro, R. \& J. Roberts. 2008. Movement and Agreement in Italian Past Participles and Defective Phases. Linguistic Inquiry 39(3). 477-591.

Embick, D. 2003. Unaccusative Syntax and Verbal Alternations. In A. Alexiadou, E. Anagnostopoulou \& M. Everaert (eds.), The Unaccusativity Puzzle Oxford Studies in Theoretical Linguistics, Oxford: University Press.

Embick, D. 2004. On the Structure of Resultative Participles in English. Linguistic Inquiry 35. 355-392. 
Fabricius-Hansen, C. \& D. Haug. 2012. Big Events, Small Clauses. Berlin/Boston: De Gruyter.

Fortmann, C. 2013. Present Participle Depictive Predicates. In C. Fortmann, W. Geuder, A. Lübbe \& I. Rapp (eds.), Situationsargumente im Nominalbereich Linguistische Arbeiten, Berlin, New York: de Gruyter.

Helland, H. P. 2013. Non-finite adjuncts in French. In T. Lohndal (ed.), In Search of Universal Grammar: From Old Norse to Zoque, 111-129. John Benjamins.

Helland, H. P. \& A. Pitz. 2012. Open adjuncts: participial syntax. In C. FabriciusHansen \& D. Haug (eds.), Big Events, Small Clauses, Berlin/Boston: De Gruyter.

Rapp, I. \& A. Lübbe. 2011. Aspekt, Temporalität und Argumentstruktur bei attributiven Partizipien des Deutschen. Zeitschrift für Sprachwissenschaft 30. 259-299.

Smith, C. 1997. The Parameter of Aspect. Dordrecht: Kluwer.

Struckmeier, V. 2007. Attribute im Deutschen. Berlin: Akademie Verlag.

Weber, H. 2000. Partizip Präsens und Partizip Perfekt im Deutschen - eine Aspektopposition? In A. Katny (ed.), Aspektualität in germanischen und slawischen Sprachen, vol. 46, Poznan.

AUTHOR CONTACT INFORMATION

Hans Petter Helland

Department of Literature, Area Studies and European Languages

University of Oslo

Norway

h.p.helland@ilos.uio.no

Anneliese Pitz

Department of Literature, Area Studies and European Languages

University of Oslo

Norway

a.p.pitz@ilos.uio.no 